BOOK REVIEWS

\section{Science and Synthesis}

Interpretations of Life and Mind. Edited by Majorie Grene. Pp. xvi+ 152. (Routledge and Kegan Paul: London, October 1971.) $£ 2.25$.

CAN anything change the headlong course of history towards greater disasters? The doctrines and religions of the past have failed to promote peace and goodwill. For some the only hope lies in the emergence of a scientific and philosophical synthesis providing not only a better image of man but a compelling vision of what mankind must achieve in this century. This major humanist aim lies behind the title of this volume. In 1965 UNESCO summoned an international colloquium of some forty scholars in memory of two world figures who died in April 1955 and provide symbols of the unifying imagination seeking to construct respectively a scientific/mathematical and a philosophical/ethical cosmology. This report, a late translation from the French edition of 1967, contributes little to the major aim, but contains much of interest on physics.

The main themes covered are Einstein and the scientific synthesis, debates on science and synthesis, and Teilhard de Chardin. The papers on the first two, with one important exception, deal principally with cosmological myths and theories, advanced physical theory, and Einstein's thought. Two call for mention: first, J. R. Oppenheimer's perceptive note on Einstein and the three traditional elements which deeply influenced him - the statistical mechanical interpretation of thermodynamics, the concept of the field, and the principle of sufficient reason-and second, a most interesting twenty-five page study by $\mathrm{G}$. Holton, using unpublished letters, of the relation of Einstein's changing philosophy of physics to Mach's positivism.

Most of the special topics discussed are old, but it is useful to have the fairly recent views of W. Heisenberg, L. de Broglie, and others on the unified field theory, from plurality to unity, determinism and indeterminism, and the organization of scientific research.

The final section on de Chardin expresses appreciation of his personality, his work on palaeontology, and his philosophical and religious doctrine. Scientists should be tolerant of speculative visions, for history shows that they can prove fertile and we are in need of unifying principles. However, in the preface to his Phenomenon of Man, de Chardin, surely unwisely, said that this book "must be read purely and simply as a scientific treatise". Why, then, do his supporters here fail to make a critical analysis of his ideas and to set them in their historical context since several influential thinkers-Berg. son, Whitehead, Smuts, and Sir Julian Huxley inter alia-have expressed similar views?

The exception referred to is a humanist manifesto by Huxley, who alone examines the perils ahead and how science and synthesis might help. Huxley is strong on diagnosis, but weak on therapy, like nearly all as yet. $\mathrm{He}$ identifies, correctly I suggest, four current insanities: military reliance on the H-bomb, economic on the profit motive, political on competitive power units, and biological on unrestricted human reproduction. When Huxley concluded, did those in agreement stand up to be counted, as a tiny nucleus of a future world consensus of the sane? Will UNESCO respond to his plea and continue the debate on the "new organized system of thought and belief (which) is the greatest task of this generation"?

A weakness of this volume is that biological synthesis is not discussed and molecular biology barely mentioned. Was not the Crick/Watson discovery of 1953 an authentic synthesis, perhaps as fertile in its own way as Einstein's metrical tensor law of 1916 ? This and other limitations are inevitable. So vast a theme could not be covered in this slim volume, for which we must be grateful; parts of it are excellent.

LANCELOT LAW WHYTE

\section{Evolution of Physics}

Bergson and the Evolution of Physics. Edited and translated by P. A. Y. Gunter. Pp. $x i+348$. (University of Tennessee: Knoxville, 1969.) $\$ 10.50$.

IN the introduction to this collection of essays Professor Gunter presents first a short history of Bergson's life. In spite of the immense success which followed the publication of L'Evolution Créatrice in 1907 (Bergson was then forty-eight years old), dark elements were not lacking in his life. The great vogue lasted only a few years, till the First World War. Then his writings were attacked with increasing violence. His influence declined and at the moment of his death in 1941, after years of illness, his way of thinking was already associated in the mind of many people with an aura of mysticism and anti-intellectualism. Even today it is often fashionable to present a few derogatory remarks about his philosophy (ref. 1 provides a recent example). Therefore the book edited by Gunter is most timely. It contains four parts: quantum physics (contributions by Louis de Broglie, Satosi Watanabé, Olivier Costa de Beauregard, Robert Blanché), relativity (Henri Bergson, Albert Einstein and Henri Piéron, André Metż and Henri Bergson, Günther Plug, J. F. Busch, W. Berteval, Olivier Costa de Beauregard), Bergson and Zeno's paradoxes (Vere C. Chappell, David A. Sipfle) and a concluding summary by Malič Čapek. Most of these articles appeared originally in French or German and have been translated for this book. Except in the section on relativity there are no original texts by Bergson.

"We interpret the past through the present." This saying is well illustrated by Louis de Broglie's article who, in his words, has "been struck by the analogy between certain new concepts of contemporary physics and certain brilliant intuitions of the philosophy of duration". The section on relativity, while it is the longest, is unfortunately the least interesting. As is well known, Bergson's specific method in metaphysics is based on what he called "intuition" and according to his words: "penser intuitivement est penser en durée"2. He felt therefore that relativity with its spatialization of time was a threat to his views. Today it may be safely stated that time is no more and no less spatialized in relativistic physics than it is in prerelativistic physics. It is as meaningful to speak of irreversibility and increase of entropy as it was before. Bergson's struggle with the Lorentz transformation in "Durée et Simultanéite" is as pathetic as it completely misses the point. In his article "The Principle of Relativity and the Spatialization of Time" de Beauregard comes closer to the issue when he notes that "Einstein's great discovery and Bergson's just claims may be less incompatible than they appear at first glance". Indeed in a recent paper Balescu and Brenig', using the recent developments in statistical mechanics, were able to prove that all relaxation times are invariants in respect to the Lorentz transformations.

Analysing the durée, Bergson reached the conclusion that time had to have attributes quite foreign to classical dynamics: "Plus profondément nous pénétrons l'analyse de la nature du temps, mieux nous comprenons que durée signifie invention, création de formes, élaboration continue de ce qui est absolument neuf"' It is indeed quite remarkable how close these views are from those reached in thermodynamics of irreversible processes (see especially refs. 5 and 6 ). 